\title{
The effect of co-infection with hepatitis B and hepatitis C viruses on the prevalence of proteinuria and loss of renal function: a single-center experience
} Amin R. Soliman, Rabab M. Ahmed, Mahmoud Soliman, Ahmed Abdallah, Bahaa Zayed

Department of Internal Medicine, Faculty of Medicine, Cairo University, Cairo, Egypt

Correspondence to Rabab M. Ahmed, MD, Department of Internal Medicine, Cairo University, Cairo, Egypt Tel: +20 106013 9196; e-mail: ruby_mahmoud_555@yahoo.com

Received 10 July 2018

Accepted 12 August 2018

The Egyptian Journal of Internal Medicine 2018, 30:271-275

\begin{abstract}
Introduction and aim of the work
Patients infected with hepatitis B virus (HBV) or hepatitis C virus (HCV) are at increased risk of renal disease. This study compares factors associated with proteinuria and doubling of serum creatinine level in patients who were infected with HCV or HBV alone with those who were coinfected with HCV and HBV.

Materials and methods

The study was performed on 1243 patients who were diagnosed with HBV and/or $\mathrm{HCV}$ at the Cairo University Hospitals. All the included subjects underwent urine analysis for proteinuria and serum creatinine level. Clinical characteristics were recorded at baseline and at last follow-up.

Results

Of 1243 patients, $293(23.6 \%)$ patients had proteinuria. Subset analysis of the patients with proteinuria showed that $10.6 \%$ were HBV infected, $63.8 \%$ were HCV infected, and the remaining $25.6 \%$ were coinfected with both HBV and HCV. Overall, coinfection with both viruses $(P=0.01)$, lower serum albumin $(P=0.001)$, hypertension $(P=0.01)$, and diabetes $(P=0.001)$ were associated with an increase in risk of proteinuria. Coinfection $(P=0.001)$, presence of HBV $(P=0.001)$, and increasing HCV RNA level in patients with HCV and in coinfected patients $(P=0.05)$ was associated with doubling of serum creatinine level.

\section{Conclusion}

The patients coinfected with HBV and HCV are at greater risk of clinically significant proteinuria and loss of renal function owing to complex virological profile. Progressive loss of renal function in that population is associated with markers of viral activity such as proteinuria and increasing HCV RNA levels among HCVinfected patients.
\end{abstract}

\author{
Keywords: \\ co-infection, creatinine, hepatitis, proteinuria \\ Egypt J Intern Med 30:271-275 \\ (c) 2019 The Egyptian Journal of Internal Medicine \\ 1110-7782
}

\section{Introduction}

In Egypt, $\sim 15 \%$ of the population is infected with hepatitis $\mathrm{C}$ virus (HCV) and $8 \%$ is infected with hepatitis $\mathrm{B}$ virus $(\mathrm{HBV})$. Both viruses represent a major endemic medical health problem in our country $[1,2]$. They are not only associated with end-stage liver disease and hepatocellular carcinoma, the most frequent causes of death in patient with liver disease, but also with various extrahepatic manifestations [3-7]. In addition to symptomatic disease, clinically silent glomerular disease has been described in these patients in the form of elevated serum creatinine, microscopic hematuria, and/or proteinuria $[8,9]$. Proteinuria has been shown to be an early diagnostic marker of kidney damage and can predict the progression of renal disease. Protein overload can upregulate complement cascade and various proinflammatory, vasoactive, and fibrogenic genes in proximal tubular cells leading to apoptosis of proximal tubules [10-20]. Many studies, such as the ALLHAT [21], INSIGHT [22,23], and LIFE [24], have shown that increasing proteinuria and deterioration of renal function are associated with poorer outcomes from vascular disease, higher incidence of cardiovascular events, and fatal and nonfatal stroke in both diabetic and nondiabetic patients. Microalbuminuria is also associated with a failure of nocturnal dipping in blood pressure, insulin resistance, and abnormal vascular responses to various stimuli [25-27]. Therefore, reducing proteinuria is a well-known renoprotective approach in nephrology. Proteinuria is a modifiable risk factor and can be managed by treating its cause. In this line of

This is an open access journal, and articles are distributed under the terms of the Creative Commons Attribution-NonCommercial-ShareAlike 4.0 License, which allows others to remix, tweak, and build upon the work non-commercially, as long as appropriate credit is given and the new creations are licensed under the identical terms. 
concept, the Kidney Disease Improving Global Outcomes clinical practice guidelines recommend screening for kidney disease at the time of $\mathrm{HCV}$ diagnosis $[28,29]$. Complex virological profiles may be present in infected patients, and dually infected patients are an extremely heterogeneous population [30]. This study assesses factors associated with proteinuria and doubling of serum creatinine level among patients infected with $\mathrm{HBV}$ or $\mathrm{HCV}$ alone or coinfected with both viruses.

\section{Materials and methods}

This is a prospective study conducted at the Cairo University Hospitals, Egypt, over 2 years. Ethical and Research Committee of the National Research Centre approved the study protocol. A total of 1243 patients who were diagnosed with viral hepatitis ( $\mathrm{HCV}$ or $\mathrm{HBV}$ alone or coinfected with both) were enrolled. All patients had agreed to take part in the study and signed a declaration of informed consent form.

Clinical characteristics were recorded at baseline and at last follow-up. Co-morbid conditions such as diabetes mellitus and hypertension were recorded. Type 2 diabetes was diagnosed using the criteria proposed by the American Diabetes Association. Fasting and 2-h postprandial glucose levels in venous blood were measured with an autoanalyzer (Automated Beckman analyzer $\mathrm{Au}$ 680; Beckman Coulter Diagnostics Company, USA). Hypertension was defined as mean systolic blood pressure greater than or equal to 140 $\mathrm{mmHg}$, mean diastolic blood pressure greater than or equal to $90 \mathrm{mmHg}$, a diagnosis of hypertension, or current use of antihypertensive medications. Serum creatinine $(\mathrm{mg} / \mathrm{dl})$ and albumin $(\mathrm{g} / \mathrm{dl})$ were measured by creatinine kinetic Jaffe uncompensated method and albumin $\mathrm{BCP}$ method, respectively, by using serum sample with an autoanalyzer (Automated Beckman analyzer Au 680). A serum albumin level less than $3.5 \mathrm{~g} / \mathrm{dl}$ was considered 'low'.

Urine analyses were done in all subjects using reagentstrip tests (Albustix ${ }^{\mathrm{TM}}$; McGuff Company (McGuff), USA). Patients were considered proteinuric if the reading was equal to or greater than 1 . Patients were included in the analyses if they had at least two creatinine measures obtained at a minimum of 3 months apart. Patients were included if they had urine analysis for proteinuria at entry and on last seen visit. The serum samples were analyzed for hepatitis $\mathrm{B}$ surface antigen $(\mathrm{HBsAg})$ and anti-HCV antibody using commercially available fourth generation ELISA kits (Dialab, Wiener Neudorf,
Austria). The specificity of the kit is $99.87 \%$ and sensitivity is $100 \%$. The test is very simple and costeffective. HCV-infected patients who were positive for $\mathrm{HCV}$ antibody were further confirmed for the presence of HCV RNA by PCR as per the routine methodology used in our hospital.

\section{Statistical analyses}

Continuous data are expressed as means \pm SD. Characteristics for patients were compared using either $\chi^{2}$-test or Student's $t$-test. Multivariate binary logistic regression assessed the association between clinical variables, the presence of proteinuria, and doubling of serum creatinine level. For non-normal data, a Mann-Whitney $U$-test was performed. $P$ less than 0.05 was considered statistically significant. All statistics were carried out using SPSS, version 16 (SPSS; SPSS Inc., Chicago, Illinois, USA).

\section{Results}

\section{Proteinuria in the study population}

Of the 1243 patients, $79 \%$ were males, with a mean age of $39.2 \pm 8.4$ years. A total of 293 (23.6\%) patients had proteinuria at both initial and follow-up urine analyses studies. The remaining patients (950) with positive virology but without proteinuria were considered the control group. Their age and sex were comparable to patients with positive virology and proteinuria. The prevalence of proteinuria was the highest among patients infected with HCV alone (63.8\%), followed by coinfection (25.6\%) and HBV alone (10.6\%) (Table 1).

\section{Factors associated with proteinuria}

Results of multivariate logistic regression analyses on independent factors associated with proteinuria in patients with viral hepatitis are shown in Table 2. In proteinuric patients, coinfection with both viruses further increased the risk of proteinuria when compared with mono infection. The odds of having proteinuria in coinfected state was 1.20 when compared with $\mathrm{HBV}$ alone $(P=0.08$, not statistically significant) and 1.50 when compared with $\mathrm{HCV}$ alone ( $P=0.01$, statistically significant). Low serum albumin level had a significant overall effect on proteinuria with

Table 1 Proteinuria in patients with viral hepatitis

\begin{tabular}{lc}
\hline Patients & $N(\%)$ \\
\hline Total patients screened & $1243(-)$ \\
Total patients with proteinuria & $293(23.6)$ \\
Patients with proteinuria and HBV alone & $31(10.6)$ \\
Patients with proteinuria and HCV alone & $187(63.8)$ \\
Patients with proteinuria and both HCV and HBV & $75(25.6)$ \\
\hline
\end{tabular}

HBV, hepatitis B virus; HCV, hepatitis C virus. 
Table 2 Factors associated with increasing proteinuria in the 293 patients

\begin{tabular}{lccc}
\hline Association & OR & $\begin{array}{c}\text { Confidence } \\
\text { interval }\end{array}$ & $\begin{array}{c}P \\
\text { value }\end{array}$ \\
\hline Coinfection versus HBV alone & 1.20 & $1-1.4$ & 0.08 \\
Coinfection versus HCV alone & 1.50 & $1.3-1.7$ & $\mathbf{0 . 0 1}$ \\
Low serum albumin & 1.96 & $1.6-2.2$ & $\mathbf{0 . 0 0 1}$ \\
$\quad$ Low serum albumin and HBV & 1.6 & & $\mathbf{0 . 0 1}$ \\
alone & & & \\
$\quad$ Low serum albumin and HCV & 2.4 & & $\mathbf{0 . 0 0 1}$ \\
alone & & & \\
$\quad$ Low serum albumin and & 1.9 & & $\mathbf{0 . 0 0 1}$ \\
coinfection & & & \\
Presence of hypertension & 1.50 & $1.2-1.7$ & $\mathbf{0 . 0 1}$ \\
hypertension and HBV alone & 1.4 & & $\mathbf{0 . 0 1}$ \\
hypertension and HCV alone & 1.6 & & $\mathbf{0 . 0 1}$ \\
Hypertension and coinfection & 1.5 & & $\mathbf{0 . 0 1}$ \\
Presence of diabetes & 3.2 & & $\mathbf{0 . 0 0 1}$ \\
$\quad$ DM and HBV alone & 2.8 & & $\mathbf{0 . 0 1}$ \\
DM and HCV alone & 3.6 & $2.9-3.6$ & $\mathbf{0 . 0 0 1}$ \\
DM and coinfection & 3.4 & & $\mathbf{0 . 0 0 1}$ \\
\hline
\end{tabular}

$\mathrm{DM}$, diabetes mellitus; HBV, hepatitis B virus; $\mathrm{HCV}$, hepatitis $\mathrm{C}$ virus; $\mathrm{OR}$, odds ratio. Bold values means its statistically significant, $P<0.05$.

an odd ratio (OR) of 1.96. When serum albumin level was compared against the type of infection, neither HBV alone nor coinfection influenced the OR significantly from the overall OR (1.6 and 1.9, respectively); however, such comparison showed an OR of 2.4 for HCV alone. Hypertension had an overall OR of 1.5 , but the type of infection did not alter the OR significantly. Diabetes was the most significant factor associated with proteinuria $(\mathrm{OR}=3.2)$, and again, the type of infection did not alter the OR significantly from the overall OR.

\section{Factors associated with doubling of serum creatinine level}

$\mathrm{HBV}$ infection, with or without $\mathrm{HCV}$ coinfection, was associated with serum doubling $(P<0.001$; Table 3$)$. Hypertension in $\mathrm{HCV}$-infected patients with or without $\mathrm{HCV}$ coinfection was associated with an increased risk of doubling of creatinine level $(\mathrm{OR}=2.70)$; it was not found to be statistically significant. Increasing HCV RNA also had significant association with serum creatinine doubling in $\mathrm{HCV}$-infected patients and in coinfected patients $(P=0.05)$ (Table 3$)$.

\section{Discussion}

Proteinuria and renal diseases are often associated with diabetes mellitus and hypertension, but when we talk about endemic countries of hepatitis, we must also consider $\mathrm{HCV}$ and $\mathrm{HBV}$ as causative factors of proteinuria and kidney functions deterioration [31]. Approximately one-fourth of our cases in this study
Table 3 Factors associated with doubling of serum creatinine level in patients with proteinuria

\begin{tabular}{lccc}
\hline Association & OR & $\begin{array}{c}\text { Confidence } \\
\text { interval }\end{array}$ & $\begin{array}{c}P \\
\text { value }\end{array}$ \\
\hline $\begin{array}{l}\text { All HBV-infected patients (with or } \\
\text { without HCV) }\end{array}$ & 12.5 & $12.2-12.7$ & $\mathbf{0 . 0 0 1}$ \\
HBV alone & 11.5 & & $\mathbf{0 . 0 0 1}$ \\
HBV/HCV coinfection & 13.5 & & $\mathbf{0 . 0 0 1}$ \\
$\begin{array}{l}\text { Hypertension in HCV-infected } \\
\text { patients (with or without }\end{array}$ & 2.7 & $2.1-2.9$ & 0.06 \\
$\begin{array}{l}\text { coinfection) } \\
\text { Hypertensive HBV-infected } \\
\text { patients (without HCV) }\end{array}$ & 1 & $0.9-1.2$ & 0.3 \\
$\begin{array}{l}\text { Increasing HCV RNA in HCV- } \\
\text { infected patients (with or without } \\
\text { coinfection) }\end{array}$ & 1.0002 & $0.9-1.1$ & $\mathbf{0 . 0 5}$ \\
\hline
\end{tabular}

$\mathrm{HBV}$, hepatitis B virus; $\mathrm{HCV}$, hepatitis $\mathrm{C}$ virus; OR, odds ratio. Bold values means its statistically significant, $P<0.05$.

(23.6\%), infected with either HCV or HBV alone or with both viruses, had proteinuria. This result was expected as it has been known that chronic $\mathrm{HCV}$ had a well-recognized association with renal and extrahepatic manifestations [3]. In addition, HBV infection is also associated with renal disease, and treatment of HBV improves renal outcome [32]. Proteinuria is thought to be caused by either the deposition of immune complexes or the presence of the virus itself. In our study, the prevalence of proteinuria was higher in patients infected with $\mathrm{HCV}$. The prevalence of nephropathy in $\mathrm{HBV}$ infection is reported to be $3-20 \%$, and in $\mathrm{HCV}$ infection, it is $\sim 38 \%$ [33]. A study from an endemic area of southern Taiwan demonstrated a significant association between proteinuria and $\mathrm{HCV}(10.2 \%)$ but not HBV infections [34].

In our study, $25.6 \%$ of our patients (293 patients) had coinfection and proteinuria. Coinfection is not uncommon in endemic countries because of the shared modes of transmission, and the prevalence of dual infection varies from country to country. In Egypt, the dual infection prevalence is reported to be $0.7 \%$ whereas in India, it is 16\%. In Turkey, it is 2.6\%, and data from Spain, Italy, Japan, Taiwan, and Iran, have demonstrated that $\sim 10-15 \%$ of patients with chronic $\mathrm{HBV}$ infection are also infected with $\mathrm{HCV}$, and $~ 2-10 \%$ of anti-HCV-positive patients are also HBsAg positive [35-40]. These patients with dual infection have a higher risk of progression of their renal disease and increasing proteinuria owing to various patterns of viral replication and great variations of immune profiles.

Our study showed that, in patients with viral hepatitis, diabetes mellitus is the most significant factor associated with proteinuria followed by low serum albumin and hypertension. Coinfection is associated 
with 1.5 times the risk of proteinuria compared with $\mathrm{HCV}$ mono infection and 1.2 times the risk of proteinuria compared with $\mathrm{HBV}$ mono infection. This comes in agreement with different studies analyzing factors associated with proteinuria [34-41].

In our cases, patients infected with $\mathrm{HBV}$ with concurrent infection with $\mathrm{HCV}$ (coinfection) or even without $\mathrm{HCV}$ were associated with an increased risk of proteinuria and doubling of creatinine levels. Proteinuria in $\mathrm{HBV}$ can be mediated by immune reactions, for example, glomerular deposition of immune complexes, or virus-induced specific immunological effector mechanisms (specific T-lymphocyte or antibody), or indirect effects from virus-induced cytokines/mediators on renal tissue.

HBV antigens are also expressed in renal tubular epithelial cells [42]. They can upregulate complement-mediated inflammatory pathways and contribute to the pathogenesis of nephropathy. Finally, HBV infection has been shown to induce apoptotic damage to the renal tubular cells [42-44].

The work by Chen et al. [45] on 17758 patients with chronic HBV infection and randomly selected 71032 matched controls without HBV to assess the risk of ESRD found significant associations of end stage renal disease (ESRD) with HBV in men of any age and women younger than 60 years and concluded that $\mathrm{HBV}$-infected patients should have targeted monitoring for the development of ESRD.

However, our results are in partial agreement with the study by Lee et al. [46] that found HCV infection, but not HBV infection, was associated significantly with prevalence and CKD stage, and are in agreement with another study that found $\mathrm{HCV}$ was associated with $40 \%$ greater risk of renal insufficiency among persons who had a positive HCV antibody test as compared with those who had a negative one [47].

Increasing HCV RNA level in HCV-infected patients and in coinfected patients was associated with an increasing risk of doubling of creatinine level. This can be explained by renal parenchymal expression of CD81 and SR-B1 receptors that allow the binding of $\mathrm{HCV}$ to the cell surface and endocytosis of HCV RNA and related proteins found in mesangial cells, tubular epithelial cells, and endothelial cells of glomerular and tubular capillaries causing direct mesangial injury. In addition, toll-like receptors may have a role in recognizing molecular patterns associated with microbial pathogens like HCV RNA and induce an immune response [48].
Another explanation is kidney injury owing to systemic immune response that is mediated by cryoglobulins [49].

Finally, the non-immunological aspects of $\mathrm{HCV}$ related kidney injury cannot be ruled out because $\mathrm{HCV}$-positive patients often have insulin resistance and hyperinsulinemia, and a higher prevalence of diabetes, which itself causes proteinuria. The $\mathrm{HCV}$ core protein directly reduces expression of insulin receptor substrate proteins 1 and 2 and increases the expression of tumor necrosis factor- $\alpha$ in hepatic cells, which upregulate the expression of angiotensin II type 1 receptors in mesangial cells, thus enhancing the deleterious effects of angiotensin II in the kidney [44].

Hypertension in $\mathrm{HCV}$-infected patients was associated with risk of doubling of serum creatinine level. This can be explained by the use of angiotensin-converting enzyme inhibitors and angiotensin-receptor blockers, which are commonly used in arterial hypertension treatment and can cause elevation of serum creatinine level above the patient's baseline level. Angiotensin II constricts both the afferent and efferent arterioles, but it preferentially increases efferent arteriole resistance. This lowers intraglomerular pressure and reduces the glomerular filtration rate [50].

\section{Conclusion}

Patients coinfected with $\mathrm{HBV}$ and $\mathrm{HCV}$ are at a greater risk for clinically significant proteinuria and loss of renal function. Progressive loss of renal function is associated with markers of viral activity such as proteinuria among $\mathrm{HBV}$-infected patients and increasing $\mathrm{HCV}$ RNA levels among $\mathrm{HCV}$-infected patients. Thus, a careful evaluation of the HBV and $\mathrm{HCV}$ viremia levels is mandatory for a correct diagnosis and proper therapeutic approach.

\section{Financial support and sponsorship \\ Nil.}

\section{Conflicts of interest}

There are no conflicts of interest.

\section{References}

1 Gomaa A, Allam N, Elsharkway A, El Kassas M, Waked I. Hepatitis C infection in Egypt: prevalence, impact and management strategies. Hepat Med 2017; 9:17-25.

2 Khaled IA, Mahmoud OM, Saleh AF, Bioumie EE. Prevalence of HBV genotypes in Egypt among hepatitis patients. Mol Biol Rep 2011; 38:4353-4357

3 Morales JM, Kamar N, Rostaing L. Hepatitis C and renal disease: epidemiology, diagnosis, pathogenesis and therapy. Contrib Nephrol 2012; 176:10. 
4 Cacoub P, Comarmond C, Domont F, Savey L, Desbois AC, Saadoun D. Extrahepatic manifestations of chronic hepatitis $C$ virus infection. Ther Adv Infect Dis 2016; 3:3-14.

5 Kappus MR, Richard K. Extrahepatic manifestations of acute hepatitis B virus infection. Gastroenterol Hepatol (N Y) 2013; 9:123-126.

6 Han SH. Extrahepatic manifestations of chronic hepatitis B. Clin Liver Dis 2004; 8:403-418.

7 Baig S, Alamgir M. The extrahepatic manifestations of hepatitis B virus. J Coll Physicians Surg Pak 2008; 18:451-457.

8 Radhakrishnan J, Uppot RN, Colvin RB. Case records of the Massachusetts General Hospital. Case 5-2010. A 51-year-old man with HIV infection, proteinuria, and edema. N Engl J Med 2010; 362:636.

9 McGuire BM, Julian BA, Bynon JS Jr, Cook WJ, King SJ, Curtis JJ, et al. Brief communication: Glomerulonephritis in patients with hepatitis $C$ cirrhosis undergoing liver transplantation. Ann Intern Med 2006; 144:735.

10 Abbate M, Zoja C, Remuzzi G. How does proteinuria cause progressive renal damage? J Am Soc Nephrol 2006; 17:2974-2984.

11 Peruzzi L, Trusolino L, Amore A, Gianoglio B, Cirina P, Basso G, et al. Tubulointerstitial responses in the progression of glomerular diseases: albuminuria modulates alpha $\mathrm{v}$ beta 5 integrin. Kidney Int 1996; 50:1310-1320.

12 Wang Y, Chen J, Chen L, Tay YC, Rangan GK, Harris DC. Induction of monocyte chemoattractant protein-1 in proximal tubule cells by urinary protein. J Am Soc Nephrol 1997; 8:1537-1545.

13 Burton CJ, Combe C, Walls J, Harris KP. Secretion of chemokines and cytokines by human tubular epithelial cells in response to proteins. Nephrol Dial Transplant 1999; 14:2628-2633.

14 Drumm K, Bauer B, Freudinger R, Gekle M. Albumin induces NF-kappaB expression in human proximal tubule-derived cells (IHKE-1). Cell Physio Biochem 2002; 12:187-196.

15 Morigi M, Macconi D, Zoja C, Donadelli R, Buelli S, Zanchi C, et al. Protein overload-induced NF-kappaB activation in proximal tubular cells requires $\mathrm{H} 2 \mathrm{O} 2$ through a PKC-dependent pathway. J Am Soc Nephrol 2002; 13:1179-1189.

16 Nakajima H, Takenaka M, Kaimori J-Y., Nagasawa Y, Kosugi A, Kawamoto $\mathrm{S}$, et al. Gene expression profile of renal proximal tubules regulated by proteinuria. Kidney Int 2002; 61:1577-1587.

17 Tang S, Leung JCK, Abe K, Wah Chan K, Chan LYY, Mao Chan T, et al. Albumin stimulates interleukin-8 expression in proximal tubular epithelia cells in vitro and in vivo. J Clin Invest 2003; 111:515-527.

18 Wohlfarth V, Drumm K, Mildenberger S, Freudinger R, Gekle M. Protein uptake disturbs collagen homeostasis in proximal tubule-derived cells. Kidney Int Suppl 2003; 84:S103-S109.

19 Donadelli R, Zanchi C, Morigi M, Buelli S, Batani C, Tomasoni S, et al. Protein overload induces fractalkine upregulation in proximal tubular cells through nuclear factor kappaB- and p38 mitogen-activated protein kinasedependent pathways. J Am Soc Nephrol 2003; 14:2436-2446.

20 Zandi-Nejad K, Eddy AA, Glassock RJ, Brenner BM. Why is proteinuria an ominous biomarker of progressive kidney disease? Kidney Int Suppl 2004; 92:S76-S89.

21 ALLHAT Officers and Coordinators for the ALLHAT Collaborative Research Group. Major outcomes in high-risk hypertensive patients randomized to angiotensin-converting enzyme inhibitor or calcium channel blocker vs diuretic: the antihypertensive and lipid-lowering treatment to prevent heart attack trial (allhat). JAMA 2002; 288:2981-2997.

22 Brown MJ, Castaigne A, Ruilope LM, Mancia G, Rosenthal T, de Leeuw PW, et al. INSIGHT: international nifedipine GITS study intervention as a goal in hypertension treatment. J Hum Hypertens 1996; 10 (Suppl 3): S157-S160.

23 Segura J, Campo C, Ruilope L. Effect of proteinuria and glomerular filtration rate on cardiovascular risk in essential hypertension. Kid Internat 2004; 66 Suppl 92): S45-S49.

24 Dahlöf B, Devereux RB, Kjeldsen SE, Julius S, Beevers G, de Faire U, et al. Cardiovascular morbidity and mortality in the Losartan Intervention for Endpoint Reduction in Hypertension Study (LIFE): a randomised tria against atenolol. Lancet 2002; 359:995-1003.

25 Levy J. Proteinuria, renal impairment, and death. BMJ 2006; 332 1402-1403.

26 Adinolfi L, Zampino R, Restivo L, Lonardo A, Guerrera B, Marrone A, et al. Chronic hepatitis $C$ virus infection and atherosclerosis: clinical impact and mechanisms. World J Gastroenterol 2014; 20:3410-3417.
27 Aghemo A, Prati G, Rumi M, Soffredini R, D’Ambrosio R, Orsi E, et al Sustained virological response prevents the development of insulin resistance in patients with chronic hepatitis C. Hepatology 2012; 56:1681-1687

28 Levey AS, Atkins R, Coresh J, Cohen EP, Collins AJ, Eckardt KU, et al. Chronic kidney disease as a global public health problem: approaches and initiatives - a position statement from Kidney Disease Improving Global Outcomes. Kidney Int 2007; 72:247.

29 Castillo I, Martinez-Ara J, Olea T, Bartolomé J, Madero R, Hernández E, et al. High prevalence of occult hepatitis $C$ virus infection in patients with primary and secondary glomerular nephropathies. Kidney Int 2014; 86:619.

30 Caccamo G, Saffioti F, Giovanni R. Hepatitis B virus and hepatitis C virus dual infection. World J Gastroenterol 2014; 20:14559-14567.

31 Hill NR, Fatoba ST, Oke JL, Hirst JA, O'Callaghan C, Lasserson DS, et al. Global prevalence of chronic kidney disease - a systematic review and meta-analysis. PLoS One 2016; 11:e0158765.

32 Tang S, Lai FM, Lui YH, Tang CS, Kung NN, Ho YW, et al. Lamivudine in hepatitis B-associated membranous nephropathy. Kidney Int 2005; 68:1750-1758.

33 Kong X-L., Ma X-J., Su H, Xu D-M. Relationship between occult hepatitis B virus infection and chronic kidney disease in a Chinese population-based cohort. Chronic Dis Transl Med 2016; 2:55-60.

34 Huang JF, Chuang WL, Dai CY, Ho CK, Hwang SJ, Chen SC, et al. Viral hepatitis and proteinuria in an area endemic for hepatitis $B$ and $C$ infections: another chain of link? J Intern Med 2006; 260:255-262.

35 Daw MA, Shabash A, El-Bouzedi A, Dau A. A seroprevalence of HBV, HCV \& HIV co-infection and risk factors analysis in Tripoli-Libya. PLoS One 2014; 9:e98793. https://doi.org/10.1371/journal.pone.0098793.

36 Pallas JR, Farinas-Alvarez C, Prieto D, Delgado-Rodríguez M. Coinfections by HIV, hepatitis $B$ and hepatitis $C$ in imprisoned injecting drug users. Eur $J$ Epidemiol 1999; 15:699-704.

37 Reddy GA, Dakshinamurthy KV, Neelaprasad P, Gangadhar T, Lakshmi V. Prevalence of HBV and HCV dual infection in patients on haemodialysis. Indian J Med Microbiol 2005; 23:41-43.

38 Aroldi A, Lampertico P, Montagnino G, Patrizia P, Margherita V, Maria CR. et al. Natural history of hepatitis $B$ and $C$ in renal allograft recipients. Transplantation 2005; 79:1132-1136.

39 Kalinowska-Nowak A, Boci囚ga-Jasik M, Garlicki A. Prevalence of hepatotropic viruses HBV and HCV in HIV-infected patients from Southern region of Poland. Acta Virologica 2000; 44:23-28.

40 Irshad M, Peter S. Spectrum of viral hepatitis in thalassemic children receiving multiple blood transfusions. Indian J Gastroenterol 2002; 21:183-184.

41 Viswanathan V, Tilak $\mathrm{P}$, Kumpatla $\mathrm{S}$. Risk factors associated with the development of overt nephropathy in type 2 diabetes patients: a 12 years observational study. Indian J Med Res 2012; 136:46-53.

42 Deray G, Buti M, Gane E, Jia JD, Lik Yuen Chan H, Craxi A, et al. Hepatitis B virus infection and the kidney: renal abnormalities in HBV patients, antiviral drugs handling, and specific follow-up. Advances Hepatol 2015 2015:596829.

43 Bhimma R, Hammond MG, Coovadia HM, Adhikari Catherine M, Connolly A. HLA class I and II in black children with hepatitis B virus-associated membranous nephropathy. 61 2002; 61:1510-1515.

44 Perico N, Cattaneo D, Bikbov B, Remuzzi G. Hepatitis C infection and chronic renal diseases. CJASN 2009; 4:207-220.

45 Chen YC, Su YC, Li CY, Wu CP, Lee MS. A nationwide cohort study suggests chronic hepatitis $B$ virus infection increases the risk of end-stage renal disease among patients in Taiwan. Kidney Int 2015; 87:1030-1038.

46 Lee JJ, Lin MY, Yang YH MHA, Yang YH, Lu SN, Chen HC, et al. Association of hepatitis $C$ and $B$ virus infection with CKD in an endemic area in Taiwan: a cross-sectional study. Am J Kidney Dis 2010; 56:23-31.

47 Dalrymple LS, Koepsell T, Sampson J, Dominitz JA, Young B, Kestenbaum B. Hepatitis C Virus Infection and the Prevalence of Renal Insufficiency. CJASN 2007; 2:4715-4721.

48 Wörnle M, Schmid H, Banas B, Merkle M, Henger A, Roeder M, et al. Nove role of toll-like receptor 3 in hepatitis $\mathrm{C}$-associated glomerulonephritis. Am J Pathol 2006; 168:370-385.

49 Fabrizi F. Hepatitis $C$ virus, cryoglobulinemia, and kidney: novel evidence. Scientifica 2012; 2012:128382

50 Cohen DL, Townsend RR. What should the physician do when creatinine increases after starting an angiotensin-converting enzyme inhibitor or an angiotensin receptor blocker? JCH 2008; 10:803-804. 